\title{
ANALISIS KELAYAKAN PENDIRIAN UNIT PRODUKSI DI UNIVERSITAS (STUDI KASUS INDUSTRI MINYAK ATSIRI)
}

\begin{abstract}
Ahmad Mubin ${ }^{1}$
ABSTRACT

The establishment of production unit requires fairly high investment, therefore to avoid the investment conducted which in fact will be unprofitable in the future, before implementing such investment, the comprehensive analysis or feasibility study is required, concerning marketing, technical, financial, management, and social-economy analysis. From the result of feasibility study, the level of feasibility for the establishment of production or business units is determined.

In this case study, the subject of study is production of essential oil that serves as raw material for food, pharmacy, and parfume manufactures.

Based on the analysis result of market and marketing aspects, as well as technical and technology aspects, it was indicated that the proposal of production unitestablishment is feasible to be accepted. Likewise, the result of financial analysis with the methods of Net Present Value, Profitability Index (B/C ratio), Internal Rate of Return and Payback Period, indicated that the proposal of production unitestablishment is feasible to be accepted.
\end{abstract}

\section{PENDAHULUAN}

Untuk menuju "The Real University" dan "Research University" yang di citacitakan, sudah barang tentu dibutuhkan dana yang sangat besar, disamping sarana-sarana pendukung lainnya. Sehingga universitas (Swasta) tidak bisa lagi hanya mengandalkan sumber-sumber dana konvensional yang selama ini dijadikan sebagai sumber utama yaitu dana yang diterima dari sumbangan mahasiswa. Hal ini karena jumlah penerimaan mahasiswa sangat fluktuatif dan seringkali sulit diprediksi tren-nya. Oleh sebab itu, universitas harus mulai memikirkan sumbersumber dana alternatif untuk menjamin agar tetap bertahan kendati jumlah mahasiswa menurun, serta tetap dapat mengembangkan dirinya menuju sebuah universitas seperti yang dicita-citakan.

Sumber-sumber dana alternatif tersebut dapat diperoleh antara lain dari pendirian suatu unit produksi atau unit usaha yang prospektif yang dapat memberikan pemasukan dana bagi universitas. Manfaat lain pendirian unit produksi atau unit usaha bagi universitas adalah bisa dijadikan sebagai sarana praktik bagi mahasiswa dan diharapkan pula dapat membuka kesempatan kerja terutama bagi para alumninya.

Pendirian unit produksi atau unit usaha diperlukan investasi yang cukup besar, sehingga untuk menghindari keterlanjuran 
investasi yang ternyata di kemudian hari tidak menguntungkan, maka sebelum melakukan investasi perlu dilakukan analisis atau studi kelayakan yang menyeluruh meliputi analisis pemasaran, teknis, keuangan, manajemen dan analisis sosial ekonomi. Dari hasil analisis kelayakan akan dapat ditentukan tingkat kelayakan pendirian unit produksi dan unit usaha tersebut.

Sebagai studi kasus dalam penelitian ini digunakan unit produksi minyak atsiri yang masuk kategori Agroindustri. Minyak atsiri merupakan produk destilasi atau ekstraksi dari bagian tanaman yaitu daun, biji, batang ataupun akar. Minyak atsiri digunakan sebagai bahan baku untuk makanan, farmasi dan parfum.

Sebagai komoditas ekspor dan juga untuk memenuhi kebutuhan dalam negeri, minyak atsiri dinilai sangat prospektif dengan tingkat permintaan yang cenderung meningkat dari tahun ke tahun, sehingga peningkatan produksi dan kualitas akan dapat meningkatkan permintaan pasar, dapat meningkatkan devisa negara dan dapat memperluas lapangan kerja.

Dari uraian diatas, maka dipandang perlu dilakukan penelitian mengenai "Analisis Kelayakan Pendirian Unit Produksi di Universitas, Studi Kasus pada Industri Minyak Atsiri", sebelum unit produksi tersebut benarbenar didirikan

\section{TINJAUAN PUSTAKA}

\section{Pengertian Studi Kelayakan Proyek}

Studi kelayakan proyek adalah penelitian tentang dapat tidaknya suatu proyek (proyek investasi) dilaksanakan dengan berhasil.

\section{Aspek Pasar dan Pemasaran}

\section{Peramalan Permintaan}

Peramalan (forecasting) permintaan merupakan kegiatan untuk memperkirakan permintaan pada masa yang akan datang. Metode-metode peramalan yang digunakan antara lain adalah metode trend linier dan eksponensial. (Assauri, 1984).

\section{Strategi Pemasaran}

Strategi pemasaran adalah berbagai usaha yang perlu dilakukan oleh calon investor dalam mempengaruhi keputusan konsumen untuk melakukan pembelian hasil produksinya.

\section{Aspek Teknis dan Teknologi}

Aspek teknis merupakan suatu aspek yang berkenaan dengan proses pembangunan proyek secara teknis dan pengoperasiaannya setelah proyek tersebut selesai dibangun. Berdasarkan analisa ini dapat diketahui rancangan awal penaksiran biaya investasi termasuk biaya eksploitasinya.

\section{Aspek Keuangan}

Aspek finansial (keuangan) biasanya dilakukan setelah evaluasi aspek-aspek yang lain selesai dianalisa. Selama evaluasi aspek ini, akan dihitung perkiraan jumlah dana atau modal yang yang diperlukan untuk investasi, 
baik itu untuk pengadaan modal tetap proyek, maupun kebutuhan modal kerja awal. Dari segi keuangan, rencana proyek ataupun pengembangan usaha dapat dikatakan sehat apabila dapat memberikan keuntungan yang layak dan mampu memenuhi kewajiban finansialnya.

Data yang diperoleh selanjutnya dilakukan analisis. Adapun analisis yang dilakukan meliputi; analisis aspek pasar dan pemasaran, aspek teknik dan teknologi serta aspek finansial.

\section{Aspek Pasar}

Meliputi, Permintaan Pasar, Permintaan Potensial, Pangsa Pasar dan Analisis Kekuatan, Kelemahan, Peluang dan Ancaman.

\section{Strategi Pemasaran}

Strategi pemasaran akan terangkum dalam bauran pemasaran perusahaan yang meliputi rencana produk (berbagai macam minyak atsiri), harga (sesuai pasar), distribusi dan promosi yang akan dilakukan perusahaan.

\section{Aspek Finansial}

Aspek finansial meliputi perhitungan yang menyangkut aliran masuk dan keluar dari seluruh biaya perusahaan.

\footnotetext{
Perhitungan Depresiasi

* Perhitungan Aliran Kas Perusahaan

* Perhitungan Cash Flow

*riteria Investasi
}

Untuk menilai kelayakan investasi yang diusulkan dapat diterima atau ditolak, ada beberapa metode yang dapat dipergunakan, yaitu :
a. Metode Net Present Value (NPV).
b. Metode Profitability Index (B/C ratio)
c. Metode Internal Rate Of Return (IRR)
d. Metode Payback Period

\section{METODOLOGI PENELITIAN}

Metode penelitian yang digunakan adalah metode penelitian tindakan (action research) yaitu penelitian yang dikembangkan bersama-sama antara peneliti dan decision maker tentang variabel-variabel yang dapat dimanipulasikan dan segera digunakan untuk menentukan kebijakan dan pengembangan.

Data-data yang diperlukan diperoleh langsung dari perusahaan ataupun dari datadata skunder yang meliputi :

$>$ Data permintaan produk, harga satuan produk dan kapasitas perusahaan

> Kebutuhan bahan baku dan bahan pembantu

$>$ Kebutuhan tenaga kerja

$>$ Biaya produksi dan Biaya Operasional

\section{HASIL DAN PEMBAHASAN}

\section{Aspek Pasar}

\section{Permintaan Pasar}

Minyak atsiri yang dihasilkan dari tanaman merupakan bahan yang banyak digunakan oleh industri, terutama industri farmasi, makanan dan parfum. 
Tabel 1

Eksport Minyak Atsiri dan Resinoid (Essential Oil \& Resinoid)

\begin{tabular}{|c|c|c|c|c|c|}
\hline NO. & TAHUN & JUMLAH (KG) & NILAI (US \$) & HARGA SATUAN RATA-RATA & KET. \\
\hline 1 & 1993 & 1272328.8 & 64146046 & 50.4162 & 46.3985 \\
\hline 2 & 1994 & 1676227.2 & 77774472 & 44.8085 & \\
\hline 3 & 1995 & 1794495.7 & 80408700 & 34.4590 & 53.9881 \\
\hline 5 & 1996 & 2276386.8 & 78441950 & 51.4802 & \\
\hline 6 & 1997 & 1652288.4 & 89203860 & & \\
\hline
\end{tabular}

Sumber : BPS Jakarta

\section{Eksport Minyak Atsiri \& Resinoid}
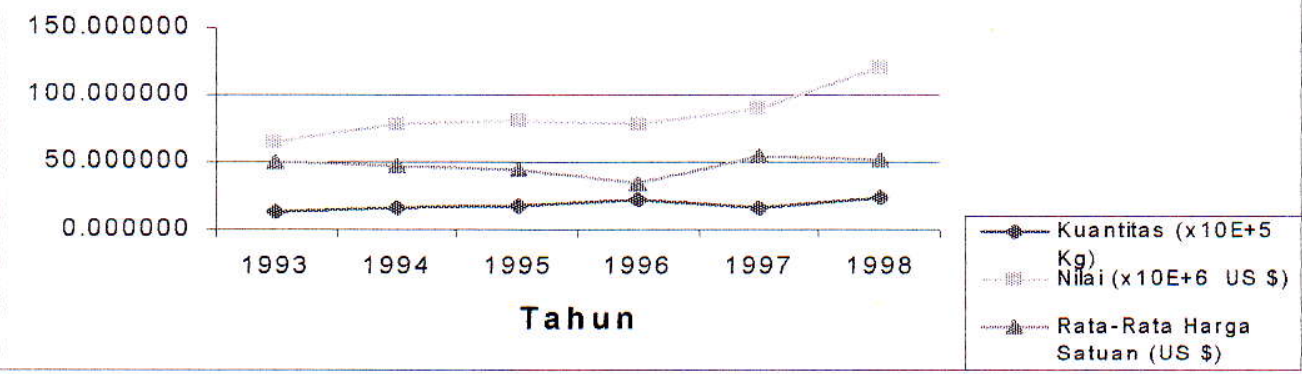

\section{Analisa Permintaan Potensial}

Untuk mengetahui besarnya

permintaan potensial maka perlu meramalkan besar permintaan produk ini pada masa mendatang dengan menggunakan metode
Trend Linier atau Metode Exponential Smoothing.

Berdasrkan scatter diagram diatas yang cenderung linier, maka metode peramalan yang digunakan adalah metode Trend Linier sebagai berikut

Tabel 2

Peramalan Permintaan

\begin{tabular}{|c|c|c|c|c|c|c|c|}
\hline Prd & $\mathbf{Y}_{\mathbf{t}}$ & $\mathbf{X}_{\mathbf{t}}$ & $\mathbf{X}_{\mathbf{t}}^{\mathbf{2}}$ & $\mathbf{Y}_{\mathbf{t}}^{\mathbf{2}}$ & $\mathbf{Y}_{\mathbf{t}} \mathbf{X}_{\mathbf{t}}$ & $\mathbf{Y}_{\mathbf{t}}{ }^{\prime}$ & $\left(\mathbf{Y}_{\mathbf{t}} \mathbf{Y}_{\mathbf{t}}\right)^{\mathbf{2}}$ \\
\hline \hline 1 & 1272328.8 & -3 & 9 & 1618820575309 & -3816986 & 1384313.4 & 12540561035.7 \\
\hline 2 & 1676227.2 & -2 & 4 & 2809737626020 & -3352454 & 1556640.8 & 14300907065.0 \\
\hline 3 & 1794495.7 & -1 & 1 & 3220214817318 & -1794496 & 1728968.2 & 4293853256.2 \\
\hline 5 & 2276386.8 & 1 & 1 & 5181936863214 & 2276387 & 2073623.0 & 41113158590.4 \\
\hline 6 & 1652288.4 & 2 & 4 & 2730056956775 & 3304577 & 2245950.4 & 352434570244.0 \\
\hline $\mathrm{Jml}$ & 1140736046.4 & 3 & 9 & 7485949902953 & 8208139 & 2418277.8 & 100976883146.0 \\
\hline
\end{tabular}


$\mathrm{SEE}=362512,05 ; \mathrm{a}=1901295,6 ; \mathrm{b}=172327,4$

Persamaan Regresi Trend Linier :

$Y^{\prime}=1901295,6+172327,4 X_{t}$

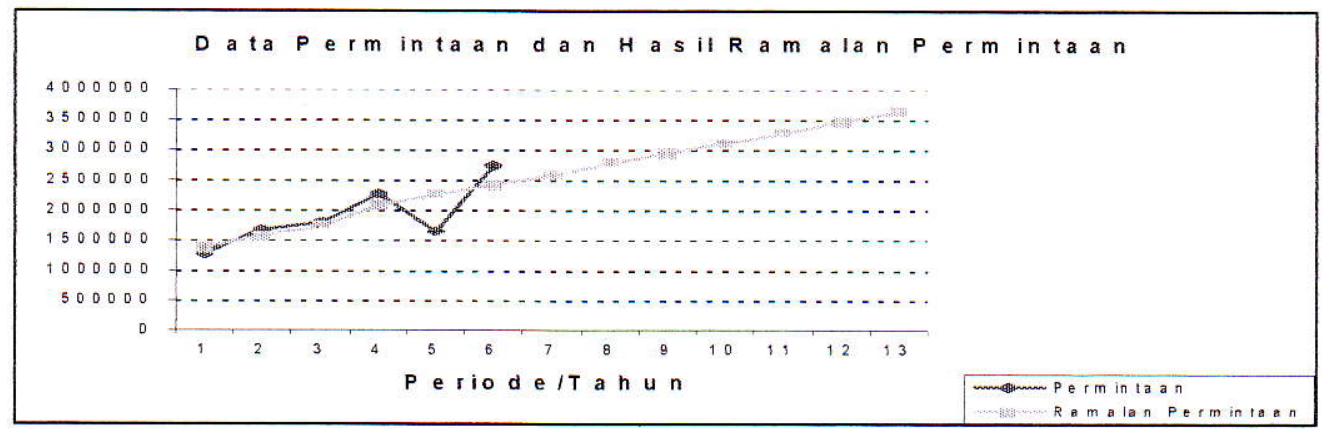

Pangsa Pasar

Berdasarkan hasil peramalan tingkat permintaan yang ada dan kemampuan yang dimiliki perusahaan maka dapat diketahui berapa target pangsa pasar yang ingin dicapai olehperusahaan.

Tabel 3

Target pangsa pasar tahun $2001-2005$

\begin{tabular}{|c|c|c|c|c|c||}
\hline NO. & TAHUN & $\begin{array}{c}\text { PERAMALAN } \\
\text { PERMINTAAN } \\
\text { (KG) }\end{array}$ & $\begin{array}{c}\text { KAPASITAS } \\
\text { PRODUKSI } \\
\text { (KG) }\end{array}$ & $\begin{array}{c}\text { TARGET } \\
\text { PANGSA PASAR } \\
(\%)\end{array}$ & KET. \\
\hline \hline 1 & 2001 & 2935260.0 & 11700 & 0.399 & 0.397 \\
\hline 2 & 2002 & 3107587.4 & 12350 & 0.396 & \\
\hline 3 & 2003 & 3279914.8 & 13000 & 0.377 & \\
\hline 5 & 2004 & 3452242.2 & 13000 & 0.359 & \\
\hline
\end{tabular}

Produksi pada tahun pertama dan kedua belum dapat mencapai kapasitas normal secara penuh. Pada tahun pertama hanya $90 \%$ dan tahun kedua $95 \%$ dari kapasitas normal, karena diperkirakan pada tahun pertama dan kedua tersebut tenaga kerja masih belum berpengalaman. Sehingga kapasitas normal diperkirakan dapat tercapai mulai tahun ketiga dan seterusnya.
Analisis Kekuatan, Kelemahan, Peluang dan Ancaman

Berdasarkan informasi yang telah diperoleh maka dilakukan analisis kekuatan, kelemahan, peluang dan ancaman atau yang dikenal dengan analisis SWOT (Strength, Weakness, Opportunities, Threaten) sebagai berikut :

\section{Kekuatan}

a. Sedikitnya pesaing di Indonesia 
b. Perusahaan di bawah permodalan yayasan yang telah mapan

c. Sumber daya manusia dan sumber daya lain telah siap dikembangkan

d. Sumber bahan baku relatif dekat dan sebagian akan di budidayakan sendiri

e. Jalur distribusi pemasaran produk yang relatif muda

\section{Kelemahan}

a. Tenaga kerja masih relatif kurang berpengalaman

b. Kapasitas produksi masih terbatas

\section{Peluang}

a. Besarnya permintaan produk minyak atsiri oleh konsumen luar negeri dan diketahui dari tahun ke tahun semakin meningkat.

b. Semakin membaiknya kondisi sosial politik Indonesia, sehingga akan menambah kepercayaan asing kepada Indonesia. Dengan demikian akan semakin banyak importir asing yang akan mengimpor barang dari Indonesia.

c. Semakin membaiknya perekonomian Indonesia, maka semakin banyak pula industri yang akan didirikan, sengga akan memperluas pasaran domestik minyak atsiri.

\section{Ancaman}

a. Jika terjadi kekacauan dalam negeri sehingga dapat kelangsungan produksi serta dapat menghambat menghambat jalur pemasaran produk.

b. Munculnya pesaing-pesaing yang tidak sehat

\section{Strategi Pemasaran}

Strategi pesaran akan terangkum dalam bauran pemasaran perusahaan yang meliputi rencana produk (berbagai macam minyak atsiri), harga (sesuai pasar), distribusi dan promosi yang akan dilakukan perusahaan untuk memasarkan produknya.

\section{Aspek Teknik dan Teknologi}

Analisis aspek teknik dan teknologi dilakukan setelah evaluasi aspek pemasaran menunjukkan prospek yang baik bagi perusahaan yang diusulkan atau direncanakan. Analisa aspek teknik meliputi penentuan lokasi perusahaan, jenis peralatan yang diperlukan dan proses produksi yang dilakukan.

\section{Lokasi Perusahaan}

Jenis perusahaan yang akan didirikan lebih berorientasi kepada bahan baku. Kendatipun demikian, faktor-faktor lain yang dapat mempengaruhi kelancaran proses produksi dan pemasaran juga tidak boleh diabaikan. Penentuan lokasi perusahaan yang tepat akan dapat meminimumkan biaya, baik biaya investasi maupun biaya eksploitasi. Dengan kata lain bahwa penempatan lokasi perusahaan yang tepat yaitu yang dapat memberikan total biaya yang rendah dan keuntungan yang maksimal.

\section{Peralatan yang diperlukan}

Peralatan yang diperlukan meliputi :

1. 1 buah Mesin diesel

2. 10 buah tanki kapasitas 1 ton bahan baku+ pipa

3. 1 buah mobil bak 
4. 1 buah mesin perajang daun/bunga

5. I buah mesin pembuat bubuk

6. Peralatan lain-lain

7. Bangunan terdiri atas ; bangunan pabrik, gudang bahan baku, gudang produk dan gudang stok bahan bakar.

\section{Proses Produksi}

Proses produksi yang akan diterapkan pada perusahaan ini adalah tidak terlalu baku karena tergantung jenis bahan yang akan dipakai. Misalnya ada bahan baku tertentu perlu dilakukan pengeringan secukupnya, ada yang perlu dirajang dan ada yang perlu dihaluskan lebih dulu serta ada pula yang langsung bisa diproses. Akan tetapi secara umum proses produksinya meliputi :

1. Tahap I. Penyiapan bahan baku sesuai sifat dan proses yang digunakan

2. Tahap II. Bahan baku yang telah siap didestilasi

3. Tahap III. Penampungan destilat atau atau hasil destilasi.

\section{Aspek Finansial}

Aspek finansial meliputi perhitungan yang menyangkut aliran masuk dan keluar dari seluruh biaya perusahaan.

\section{Perhitungan Depresiasi}

Metode yang digunakan adalah metode garis lurus dengan hasil perhitungan nilai akhir dan nilai buku mesin, peralatan dan bangunan dapat dilihat pada tabel berikut :

\section{Tabel 4}

Hasil Perhitungan Nilai Akhir Mesin, Peralatan dan Bangunan pada Tahun 2005

\begin{tabular}{|c|l|r|}
\hline No. & \multicolumn{1}{|c|}{ Uraian } & Nilai Akhir \\
\hline \hline 1 & Mesin Diesel & 3.250 .000 \\
\hline 2 & Tanki Proses & 5.000 .000 \\
3 & Mobil Bak & 15.000 .000 \\
\hline 4 & Mesin Perajang Daun/Bunga & 300.000 \\
5 & Mesin Pembuat Bubuk & 400.000 \\
\hline 6 & Peralatan Lain-Lain & 200.000 \\
\hline 7 & Bangunan & 46.666 .665 \\
& Jumlah & 70.816 .665 \\
\hline \hline
\end{tabular}

Tabel 5

Hasil Perhitungan Nilai Buku Mesin, Peralatan dan Bangunan pada Tahun 2000

\begin{tabular}{|c|l|r|}
\hline No. & \multicolumn{1}{|c|}{ Uraian } & \multicolumn{1}{|c|}{ Nilai Buku } \\
\hline \hline 1 & Mesin Diesel & 5.000 .000 \\
\hline 2 & Tanki Proses & 30.000 .000 \\
\hline 3 & Mobil Bak & 18.000 .000 \\
\hline 4 & Mesin Perajang Daun/Bunga & 1.500 .000 \\
\hline 5 & Mesin Pembuat Bubuk & 2.000 .000 \\
\hline 6 & Peralatan Lain-Lain & 1.500 .000 \\
\hline 7 & Bangunan & 50.000 .000 \\
\hline & Jumlah & 108.000 .000 \\
\hline
\end{tabular}

Tabel 6

Perkiraan Hasil Penjualan Minyak Atsiri

\begin{tabular}{|c|c|c|c|c|c|c||}
\hline \hline Tahun & $\begin{array}{c}\text { Ramalan } \\
\text { Permintaan (Kg) }\end{array}$ & $\begin{array}{c}\text { Kapasitas } \\
(\mathbf{K G )}\end{array}$ & $\begin{array}{c}\text { Target Pangsa } \\
\text { Pasar (\%) }\end{array}$ & $\begin{array}{c}\text { Harga } \\
\text { Satuan } \\
\text { (US S) }\end{array}$ & $\begin{array}{c}\text { Penerimaan } \\
\text { (US S) }\end{array}$ & $\begin{array}{c}\text { Penerimaan } \\
\text { (Rp) }\end{array}$ \\
\hline \hline 2001 & 2935260.0 & 11700 & 0.399 & 48.641 & 569099.70 & 3983697900.0 \\
\hline 2002 & 3107587.4 & 12350 & 0.397 & 48.927 & 604248.45 & 4229739150.0 \\
\hline 2003 & 3279914.8 & 13000 & 0.396 & 49.213 & 639769.00 & 4478383000.0 \\
\hline 2004 & 3452242.2 & 13000 & 0.377 & 49.499 & 643487.00 & 4504409000.0 \\
\hline 2005 & 3624569.6 & 13000 & 0.359 & 49.785 & 647205.00 & 4530435000.0 \\
\hline
\end{tabular}

Catatan : Digunakan patokan 1 US $\$=$ Rp. 7000,- 


\section{Biaya-Biaya}

Proyeksi biaya bahan baku untuk lima tahun mendatang yaitu menggunakan pendekatan tingkat laju inflasi bulan Januari 2000 sebesar 1,32\% (Sumber BPS). Hal ini dilakukan karena sulitnya mendapatkan angka laju inflasi yang tepat akibat terjadinya fluktuasi yang sangat cepat.
1. Biaya bahan baku

2. Biaya Tenaga Kerja Langsung

3. Biaya Bahan Bakar

4. Biaya Pemeliharaan dan Reparasi

5. Biaya Penjualan

6. Biaya Administrasi dan Umum

7. Biaya Penyusutan

Tabel 7

Perkiraan Pengeluaran Biaya Tahun 2001 s/d 2005

\begin{tabular}{|c|c|c|c|c|c|}
\hline \multirow[t]{2}{*}{ JENIS AKTIVA } & \multicolumn{5}{|c|}{ BIAYA PENGELUARAN PADA TAHUN (Rp) } \\
\hline & 2001 & 2002 & 2003 & 2004 & 2005 \\
\hline \multicolumn{6}{|l|}{ BIAYA PRODUKSI } \\
\hline - Bahan Baku & 2400000000 & 2431680000 & 2463778176.0 & 2496300047.9 & 2529251208.6 \\
\hline $\begin{array}{l}\text { - Tenaga Kerja } \\
\text { Langsung. }\end{array}$ & 94800000 & 96051360 & 97319238.0 & 98603851.9 & 99905422.7 \\
\hline - Overhead Pabrik & 120673334 & 122266222 & 123880136.1 & 125515353.9 & 127172156.6 \\
\hline Sub Total & 2615473334 & 2649997582 & 2684977550.1 & 2720419253.8 & 2756328787.9 \\
\hline \multicolumn{6}{|l|}{$\begin{array}{l}\text { BIAYA OPE- } \\
\text { RASIONAL }\end{array}$} \\
\hline - Penjualan & 1200000 & 1215840 & 1231889.1 & 1248150.0 & 1264625.6 \\
\hline - Adm. \& Umum & 4800000 & 4863360 & 4927556.4 & 4992600.1 & 5058502.4 \\
\hline Sub Total & 6000000 & 6079200 & 6159445.4 & 6240750.1 & 6323128.0 \\
\hline Total & 2621473334 & 2656076782 & 2691136995.5 & 2726660003.9 & 2762651915.9 \\
\hline
\end{tabular}

Biaya overhead pabrik meliputi biaya pemeliharaan \& reparasi, biaya bahan bakar dan biaya penyusutan.

Tabel 8

Proyeksi Laporan Rugi Laba Perusahaan Tahun 2001 s/d 2005

\begin{tabular}{|l|r|r|r|r|r||}
\hline \multirow{2}{*}{ URAIAN } & \multicolumn{6}{|c|}{ BIAYA PENGELUARAN PADA TAHUN (Rp) } \\
\cline { 2 - 6 } & \multicolumn{1}{|c|}{$\mathbf{2 0 0 1}$} & $\mathbf{2 0 0 2}$ & \multicolumn{1}{c|}{$\mathbf{2 0 0 3}$} & \multicolumn{1}{c|}{$\mathbf{2 0 0 4}$} & \multicolumn{1}{c|}{$\mathbf{2 0 0 5}$} \\
\hline Penjualan & 3983697900.0 & 4229739150.0 & 4478383000.0 & 4504409000.0 & 4530435000.0 \\
\hline $\begin{array}{l}\text { Biaya Prod. \& } \\
\text { Operasi }\end{array}$ & 2621473334.0 & 2656076782.0 & 2691136995.5 & 2726660003.9 & 2762651915.9 \\
\hline EBT & 1362224566.0 & 1573662368.0 & 1787246004.5 & 1777748996.1 & 1767783084.1 \\
Pajak & 399917369.8 & 463348710.4 & 527423801.4 & 524574698.8 & 521584925.2 \\
\hline EAT & 962307196.2 & 1110313657.6 & 1259822203.2 & 1253174297.3 & 1246198158.9 \\
\hline Penyusutan & 7436667.0 & 7436667.0 & 7436667.0 & 7436667.0 & 7436667.0 \\
\hline Laba Bersih & 969743863.2 & 1117750324.6 & 1267258870.2 & 1260610964.3 & 1253634825.9 \\
\hline
\end{tabular}




\section{Kriteria Investasi}

Untuk menilai kelayakan investasi yang diusulkan dapat diterima atau ditolak, ada beberapa metode yang dapat dipergunakan, yaitu :

1. Metode Net Present Value (NPV).

Tabel 9

Perhitungan Net Present Value (NPV)

\begin{tabular}{|c|c|c|r|}
\hline \multicolumn{3}{|c|}{ Initial Investment } & $\mathbf{9 0 8 , 0 0 0 , 0 0 0}$ \\
\hline \hline Tahun & Cash Inflow & $\begin{array}{c}\text { Discount } \\
\text { Factor 20\% }\end{array}$ & Present Value \\
\hline \hline 1 & 969743863.2 & 0.8333 & 808087561.2 \\
2 & 1117750324.2 & 0.6944 & 776165825.1 \\
3 & 1267258870.2 & 0.5787 & 733362708.2 \\
4 & 1260610964.3 & 0.4853 & 611774501.0 \\
5 & 1253634825.9 & 0.4019 & 503835836.5 \\
& NET PRESENT VALUE & $\mathbf{2 5 2 5 2 2 6 4 3 2 . 0}$ \\
\hline
\end{tabular}

Dari tabel diatas didapatkan bahwa dengan bunga sebesar $20 \%$ mengahsilkan Net Present Value positif sebesar Rp. 2.525.226.432,-. Dengan demikian maka usulan investasi dapat diterima.

2. Metode Profitability Index (B/C ratio)

Tabel 10

\section{Perhitungan Profitability Index (B/C ratio)}

\begin{tabular}{|c|c|c|r||}
\hline \multicolumn{3}{|c|}{ Initial Investment } & $\mathbf{9 0 8 , 0 0 0 , 0 0 0}$ \\
\hline Tahun & Cash Inflow & $\begin{array}{c}\text { Discount } \\
\text { Factor } \\
\mathbf{2 0 \%}\end{array}$ & Present Value \\
\hline 1 & 969743863.2 & 0.8333 & 808087561.2 \\
\hline 2 & 1117750324.2 & 0.6944 & 776165825.1 \\
\hline 3 & 1267258870.2 & 0.5787 & 733362708.2 \\
\hline 4 & 1260610964.3 & 0.4853 & 611774501.0 \\
\hline 5 & 1253634825.9 & 0.4019 & 503835836.5 \\
\hline & NET PRESENT VALUE & $\mathbf{2 5 2 5 2 2 6 4 3 2 . 0}$ \\
\hline & PROFITABILITY INDEX & $\mathbf{3 . 7 8}$ \\
\hline \hline
\end{tabular}

Dari tabel diatas didapatkan bahwa dengan bunga sebesar $20 \%$ mengahsilkan Profitability Index (B/C ratio) lebih besar dari satu. Dengan demikian maka usulan investasi dapat diterima

3. Metode Internal Rate Of Return (IRR)

Tabel 11

Perhitungan Internal Rate Of Return (IRR)

\begin{tabular}{|c|r|c|c|}
\hline \hline \multicolumn{3}{|c|}{ Initial Investment } & $\mathbf{9 0 8 , 0 0 0 , 0 0 0}$ \\
\hline Tahun & Cash Inflow & $\begin{array}{c}\text { Discount } \\
\text { Factor 20\% }\end{array}$ & $\begin{array}{c}\text { Present } \\
\text { Value }\end{array}$ \\
\hline 1 & 969743863.2 & 0.8333 & 808087561.2 \\
\hline 2 & 1117750324.2 & 0.6944 & 776165825.1 \\
\hline 3 & 1267258870.2 & 0.5787 & 733362708.2 \\
\hline 4 & 1260610964.3 & 0.4853 & 611774501.0 \\
\hline 5 & 1253634825.9 & 0.4019 & 503835836.5 \\
\hline & 1173799769.6 & & $\mathbf{2 5 2 5 2 2 6 4 3 2 . 0}$ \\
\hline
\end{tabular}

Payback Period

\subsection{7}

Interpolasi

$$
34 \%
$$
2.433

Rate yg dicari

$$
\begin{aligned}
& 35 \% \quad 2.385 \\
& 0.048
\end{aligned}
$$

$$
\text { IRR } \quad 34.69 \%
$$

Dari tabel diatas didapatkan bahwa dengan bunga sebesar $20 \%$ mengahsilkan Internal Rate Of Return (IRR) lebih besar dari MARR. Dengan demikian maka usulan investasi dapat diterima.

4. Metode Payback Period

Tabel 12

Perhitungan Payback Period

\begin{tabular}{|c|c|c|c|}
\hline \multicolumn{3}{|c|}{ Initial Investment : } & $\mathbf{9 0 8 , 0 0 0 , 0 0 0}$ \\
\hline Tahun & EAT & Depresiasi & Cash inflow \\
\hline 1 & 962307196.2 & $7,436,667$ & 969743863.2 \\
2 & 1110313657.2 & $7,436,667$ & 1117750324.2 \\
3 & 1259822203.2 & $7,436,667$ & 1267258870.2 \\
\hline
\end{tabular}




\begin{tabular}{|c|c|c|c||}
\hline 4 & 1253174297.3 & $7,436,667$ & 1260610964.3 \\
5 & 1246198158.9 & $7,436,667$ & 1253634825.9 \\
\hline RATA2 & 1166363102.6 & $7,436,667$ & 1173799769.6 \\
\hline
\end{tabular}

PAYBACK PERIOD

0.77 Tahun

Dari tabel diatas didapatkan bahwa dengan bunga sebesar $20 \%$ mengahsilkan Payback Period lebih kecil dari umur ekonomis. Dengan demikian maka usulan investasi dapat diterima.

\section{KESIMPULAN}

Berdasarkan hasil analisis data, maka dapat diambil kesimpulan sebagai berikut :

1. Aspek Pasar dan Pemasaran

Analisis pasar dan pemasaran menunjukkan bahwa dari hasil peramalan permintaan dengan menggunakan Metode Regresi Trend Linier, untuk lima tahun mendatang, diperoleh trend peningkatan yang positif terhadap permintaan Minyak Atsiri. Dengan demikian, maka usulan pendirian unit produksi tersebut layak untuk diterima.

2. Aspek Teknik dan Teknologi

Pada aspek teknik dan teknologi menunjukkan bahwa baik lokasi perusahaan maupun proses produksi dinilai layak untuk diterima.

3. Aspek Finansial

a. Metode Net Present Value (NPV)

Hasil perhitungan Net Present Value diperoleh NPV positif, sehingga usulan proyek dapat diterima.

b. Metode Profitability Index (B/C ratio)
Hasil perhitungan Profitability Index (B/C ratio) diperoleh lebih besar dari satu, sehingga usulan proyek dapat diterima.

c. Metode Internal Rate of Return (IRR).

Hasil perhitungan Internal Rate of Return (IRR) diperoleh lebih besar dari MARR, sehingga usulan proyek dapat diterima.

d. Metode Payback Period

Hasil perhitungan Payback Period diperoleh lebih kecil dari umur ekonomis, sehingga usulan proyek dapat diterima.

\section{DAFTAR PUSTAKA}

Ariyoto, Kresnohadi, 1995, Feasibility Study, Mutiara Sumber Widya, Jakarta.

Assauri, Sofjan, 1984 , Teknik dan Metode

Peramalan, Penerapannya dalam

Ekonomi dan Dunia Usaha, Edisi

Satu, LPFEUI, Jakarta.

Grant, Eugene L. et.al., 1991, Dasar-Dasar

Ekonomi Teknik (Alih bahasa; E. Komarudin \& G. Kartasapoetra), Jilid II, PT. Rineka Cipta, Jakarta.

Husnan, S. \& Suwarsono, 1994, Studi Kelayakan Proyek, Ed. Ke-3, BPFE, Yogyakarta.

Kotler, Philip, 1997, Manajemen Pemasaran (Alih bahasa; Hendra T. \& Ronny AR.), Jilid I, PT. Prenhallindo, Jakarta,.

Wignjosubroto, S., 1996., Tata Letak Pabrik dan Pemindahan Bahan, PT. Guna Widya, Surabaya. 